\title{
TOWARD QUEER POTENTIALITIES IN CHILD AND YOUTH CARE
}

\section{Bobbi Ali Zaman and Ben Anderson-Nathe}

\begin{abstract}
Arguably, from the invention of adolescence at the beginning of the 20th century, developmental theory has served as the foundation of disciplinary study and professional practice with children and youth across the global West. Despite their founders' assertions that development is culturally constructed, in educational and youth work practice contexts stage-based trajectories of normative human growth are largely erroneously accepted as ahistorical, apolitical, naturally occurring, and universally applicable. This paper presents critiques of developmentalism from historical, reconceptualist, and queer perspectives, calling into question the underlying principles of normalcy and abnormality that run through the developmental project. We pay particular attention to the potential of queer theory as an analytic to deconstruct developmentalism in the context of child and youth care, opening new possibilities for critical engagement with children and youth outside the context of development.
\end{abstract}

Keywords: child and youth care, early childhood education, queer theory, developmental theory, developmentalism

Bobbi Ali Zaman MEd (corresponding author) is a PhD candidate in the School of Social Work, Portland State University, 1800 SW 6th Ave., Portland, OR 97201. Email: zaman@pdx.edu

Ben Anderson-Nathe PhD is Professor in the Department of Child, Youth and Family Studies, Portland State University, 1800 SW 6th Ave., Portland, OR 97201. Email: banders@pdx.edu 
Developmental theory is ubiquitous across academic disciplines and practice fields concerned with children and youth. But its underlying principles of normalcy, abnormality, and linear progression from immaturity to maturity are not often troubled. Queering developmentalism offers an opportunity to expose and destabilize these principles, opening new possibilities for engagement with young people.

But how does one "queer" developmentalism? Or how would one go about queering the developmental assumptions that lie within a psychological framework? In considering how queer has been used theoretically to question the stability of any structured categories or to trouble a subject by making it "strange"(Somberville, 2014), what would it mean to queer the structure of developmental psychology today? Developmental theories have been troubled by many critical scholars in child and youth care (CYC; Pacini-Ketchabaw, 2012; Pence \& White, 2012). Queer and trans studies have also looked at children and youth in relation to their sociopolitical subjectivity alongside developmentalist narratives (Gill-Peterson, 2018; Meadow, 2018; Owen, 2020; Stockton, 2009). Yet queer and trans studies have rarely connected with, or made impacts on, professional practice, perspectives, and pedagogies in CYC. Therefore, this article seeks to expand on current postmodernist inquiries by considering a queer perspective as the foundation for critical interrogations of developmental theory in CYC. We suggest that queer potentialities do exist in interdisciplinary queer and trans scholarship and can link with the critical engagements of CYC to interrogate the dominant developmentalist narratives and frameworks within that field. In doing this we aim to connect CYC with queer and trans conceptualizations of children and youth through prior resistance movements and through critiques of developmentalism in early childhood education (ECE), childhood studies, youth studies, and education.

In this paper we follow a path towards what queer scholar José Esteban Muñoz (2009) has conceptualized as queer idealities - the potential of a queer future beyond the present. We do so by first outlining a brief history of developmentalism and common developmental themes and practices within CYC and ECE and focus on its direct relation to conceptualizing children and youth as socially constructed subjects. We specifically look to the National Association for the Education of Young Children's (NAEYC) developmentally appropriate practice (DAP) as a contemporary example of developmentalism in early childhood practice that is used across various programs globally. Following our examination of DAP, we explore both the reconceptualizing early childhood education (RECE) and post-developmentalist movements as counternarratives for developmentalist theories and practice frameworks in ECE. We then pivot to an introduction of queer and transgender studies and their scholarly engagements with the figure of the child, childhood, and developmentalism and hope to spark critical curiosities about these approaches within the field of CYC. Finally, we conclude with a discussion of how these prior resistance movements in ECE and queer and transgender scholarship allow for a conversation about queer potentialities in CYC. 
International Journal of Child, Youth and Family Studies (2021) 12(3/4): 104-128

For Lanser (2018), "queering" entails the disruption of an entity by rejecting its categories, binaries, and norms. Our intention in this article is to encourage an active engagement with queering in $\mathrm{CYC}$ as a tool for critically examining the field and its understanding of sexualities, identities, difference, and development. We believe that queer theory, as an analytic approach, has a place in $\mathrm{CYC}$ in relation to developmentalist frameworks that are commonplace and taken for granted in the field. In order to explore a potential queer future in CYC, we first need to understand the history of developmentalism, its modern frameworks for practice, and the contemporary resistance movements that seek to disrupt developmentalist hegemony within the field of ECE and in research.

\section{The Developmental Project}

Since its antecedents emerged in the late 18th century, developmental theory has become ubiquitous in the Global North and West, and occupies a position of nearly unquestioned hegemony in psychology, the social sciences, the human services professions, and education. The central notion of development - that humans are born into a nascent state (full of potential but not yet fully themselves) and develop over time through a series of predictable and orderly stages into the realized potential of accomplished adulthood - is accepted a priori across most sectors of society (Epstein, 2007; Owen, 2020). Colloquial applications of developmentalism also position the notion of development itself (stage-based change from an incomplete to a more complete state) as largely natural and universal, and the successful navigation of the challenges associated with its stages (whether biological, psychological, emotional, moral, or educational) as essential to human well-being (Lesko, 1996, 2001; Owen, 2020). While developmentalists from Erikson $(1950,1968)$ forward have grounded their theory in claims that development is culturally and contextually bound (e.g., Schachter, 2005), these claims largely speak to how development occurs, accepting as a starting point the notion that it occurs. This is to say that while human growth and change certainly occurs over a lifetime, development is a construction, a way of conceptualizing change that has at its core the idea of movement from a non-developed state to a developed one. In this way, the developmental project presupposes that the young are undeveloped, and that their growth is oriented toward a future developed state that privileges their potential (future adulthood) over their actual (present youth) experience.

Understandings of the meanings, significance, and navigation of childhood, youth, and adulthood differ across culture and geography, across time, and across social and economic conditions, and have not always been organized within the logic of development (Epstein, 2007; Finn, 2009; O’Loughlin \& Van Zile, 2014; Wyn \& White, 1997). Our understanding of childhood, now conceptualized as a time of idealized imaginative innocence in which children must negotiate fundamentals of attachment and agency, has changed drastically in the West over the past several centuries (Epstein, 2007). Likewise, as Lesko (1996, 2001) demonstrated, adolescence is a social construction, a product of the late-19th century that represents the culmination of a number of (gendered and racialized) social, economic, national, and political factors including but not limited to industrialization, urbanization, and their associated shifts in economic systems; the creation of 
compulsory schooling; and more. Lesko cautions against accepting any of what she names "confident characterizations" of adolescence without interrogating the cultural, historical, economic, and geographic conditions that gave rise to them. Adolescence is not, she argues, universal, nor is it naturally occurring. It is a social product, which globalization and colonization have exported across the world.

From the mid-19th to the mid-20th century, developmental theory gained traction across a variety of domains and disciplines, including education, the youth criminal justice system (with the creation of the juvenile court), and, of course, psychology itself. As indicated by the requirements for child and adolescent development coursework in most education and youth service curricula, much of the theory base in ECE and in $\mathrm{CYC}$, including the fundamental construction of youth as "adolescent", rests on developmental precepts. This adherence to a developmentalist framework is also reflected in the hiring requirements in the field where, for example, a quick internet search of CYC job postings in Vancouver, British Columbia, ${ }^{1}$ reveals positions calling for coursework "relevant to child development" or "knowledge and understanding of child development principles and techniques". Similarly, position titles for youth work employment in the United States often include "adolescent" as a main descriptor of their focus population.

In practice, this reliance on developmentalism shows up in the use of DAP in ECE, and in the contemporary discourse on the "adolescent brain" in youth services. Discourse on the adolescent brain that completely accepts developmental constructs of adolescence effectively renders these constructs as biodeterministic: such discourse asserts that the origins of developmental constructs rest in the undeveloped brains of young people (Males, 2009; Sercombe, 2010). Put differently, constructing the brain as "adolescent" provides a preexisting interpretative frame for findings that the brain changes over time. For example, developmentalist assumptions about young people may lead to findings about the brain's plasticity being interpreted as explaining adolescent indecision or impulsivity, and not in terms of creativity or adaptability (Males, 2009). These associations between the young adult brain and adolescent behavior depend upon an accepted interpretation of adolescents as inherently impulsive and lacking in cognitive maturity; absent this interpretative framework of adolescence, impulsivity could be interpreted as curiosity and cognitive maturity could be viewed as signaling intellectual stagnation. This is not to suggest that brain research teaches nothing, but rather that how we interpret findings means as much as or more than the findings themselves (Sercombe, 2010). Nevertheless, the discourse of neuroimaging (brain imaging) which provides evidence of physiological differences in the human brain at different ages is now so thoroughly orthodox as to be introduced as evidence in the U.S. Supreme Court (e.g., Roper v. Simmons, 2005; Terrell v. State of Ohio, 2018).

We are interested in queering developmentalism and challenging its ubiquity in our field by considering who, and how, children and youth are in the immediate moment, rather than staging

${ }^{1}$ https://ca.indeed.com/jobs?q=Child + Youth + Care\&l=Vancouver $\% 2 \mathrm{C}+\mathrm{BC}$ 
International Journal of Child, Youth and Family Studies (2021) 12(3/4): 104-128

them along a trajectory towards a predicted future outcome. We suggest that new possibilities for CYC could be opened by critically examining developmentalism and examining cases of children and contexts that do not conform to the tidy benchmarks offered up by ages and stages orientations. This project not only opens space to queer "how" development occurs, but also for queering the notion that young people's growth and change must by definition constitute "development" in the first place.

\section{Early Childhood Education and Developmentally Appropriate Practice}

In considering stage-based developmentalism's hegemony, we can look to ECE and its historical relationship with developmental psychology, specifically the work of Swiss psychologist Jean Piaget (Mooney, 2005). Piaget has not only influenced how the child is understood to develop cognitively, but how practice-based approaches in teaching and education should be appropriately constructed. In ECE, in other words, determinations of what is good or bad, and appropriate or inappropriate, in curriculum, social-emotional education and intervention, and even center design, are made according to assessments of children's locations along a fixed developmental trajectory.

\section{Jean Piaget and DAP}

One cannot complete an ECE, CYC, or Social Work college or university training program in North America without exploring theories that derive from Piaget's cognitive developmental concepts (Council on Social Work Education, 2015; Mattingly, 2010; National Association for the Education of Young Children, 2020). Piaget still plays a monumental role in how teachers are trained and evaluated in ECE (Burman, 2016), bringing to ECE a focus on cognitive developmental theory consisting of specific stages following a predictive trajectory through which children move, and articulating how cognition develops towards appropriate cognitive "functionality" (Piaget, 1952). For Piaget, a stage is a period in which the child's thinking and behavior, in a variety of situations, tend to reflect a particular type of underlying mental structure (Miller, 2016; Piaget, 1952). These stages illustrate a linear progression of adaptation through cognitive development that is believed to be universal, and that follows a sequence in which each stage is derived from the previous stage and is a part of a larger whole (Miller, 2016). Piaget's background in zoology, biology, and epistemology (Piaget, 1952; Singer \& Revenson, 1996) is reflected in his application of biological principles of adaptation, assimilation, accommodation, and equilibrium to human cognition and development as analogies to parallel how human intelligence works (Miller, 2016; Piaget, 1952; Singer \& Revenson, 1996). In short, common assumptions made in Piaget's work promote a biological understanding of the "natural" stages of human development, thus emphasizing adults as mature, rational, and competent while children are viewed as "human-becomings", incomplete or in progress (Tisdall \& Punch, 2012).

An example of Piaget's influence on practice and early childhood knowledge can be seen in the development of the NAEYC's renowned DAP framework. Sue Bredekamp, the past Director of Accreditation and Professional Development of NAEYC, established the grounding and central principles of DAP as the primary author of the first (Bredekamp, 1987) and second (Bredekamp 
\& Copple, 1997) editions of the official publications. Child psychologist and DAP advocate David Elkind (2015) outlined the history of DAP by highlighting the "Giants" who inspired its foundational principles. Piaget is noted as being one of the "most well-known and influential of the Giants" (p. 159). By 2009, DAP had become ubiquitous in ECE, grounded as it is in Piaget's ideas of child development (Copple \& Bredekamp, 2009; National Association for the Education of Young Children, 2009). While several other theorists - also "Giants" — such as Montessori, Freud, Erikson, Dewy, and Vygotsky (Elkind, 2015) have influenced and been foundational to DAP over time, Piagetian theory is the most pervasive theoretical framework for DAP's primary principles and applications (Sanders \& Farago, 2018). Although NAEYC's (2020) most recent DAP position statement no longer directly references Piaget's work, his ideas remain implicitly embedded in DAP and across the peer-reviewed articles, books, blog posts, and media promoted through NAEYC (Bohart \& Procopio, 2017; DeVries \& Sales, 2010; Koralek et al., 2015; Schaefer, 2016).

Early critiques of DAP challenged the reliance on developmentalist frameworks for researching, representing, and engaging children's lives across various fields (Burman, 2016; Flavell, 1992; Prout, 2005). Critical psychologists and sociologists called for continual interdisciplinary engagements of childhood and looked to postmodern philosophies and their deconstructive tendencies (Lyotard, 1984) to question what critical and feminist psychologist Valerie Walkerdine called "the scientific story of children's development" (1993, p. 452). Walkerdine elaborated on this critical engagement of developmental psychology:

What is important here is the kind of story which developmental psychology claims to be: a grand, totalizing story ... But this is no mere debate about true scientific stories versus false pseudo-scientific or ideological ones. Rather, it is about the place of developmental psychology stories not in telling a biased or distorted story, and so obscuring a true and proper story about children, but in actually producing, fashioning "the child" and "development". (p. 452)

In other words, this postmodern perspective reorients the question from asking which frameworks should be employed to understand the child, to instead asking how existing developmental frameworks were constructed in relation to their social, political, and historical context. Critical early childhood educators have for some time now engaged with postmodern philosophy as a way to "problematize the beliefs and practices that have guided the field of ECE to uncover hidden histories, biases, and illusions [that] risk supporting a restrictive and narrow perspective" (Cannella, 1997, p. 2). A concern that is shared by early childhood researchers and educators is this field's overwhelming prioritization of the psychological sciences and a lack of interest in alternative perspectives (Jipson, 2001). In response to the absence of ways for early educators to critically discuss their field through journals, books, and conferences, a movement began to "reconceptualize" ECE in ways that allow for an interdisciplinary questioning of the primary principles and the truth claims that dominated their fields (Bloch, 2013; Reconceptualizing Early Childhood Education, n.d.). 
International Journal of Child, Youth and Family Studies (2021) 12(3/4): 104-128

\section{Reconceptualist and Postdevelopmentalist Critical Histories in ECE}

In the late 1980s and early 1990s, a series of conferences and special journal publications, organized by critical scholars and educators, began to question developmentalism and the absence of diversity in ECE practices (Pacini-Ketchabaw \& Pence, 2005; Swadener \& Kessler, 1991). Often seen as constituting a resistance movement in ECE, critical scholars began to trouble the unquestioned modernist assumptions and privileged Euro-American knowledge that rooted DAP. As a way to create space for alternative and othered voices within ECE, these scholars called on us to reconceptualize ECE as a way to create a community of resistance that focuses on the sociopolitical impacts of developmental frameworks in their fields. This reconceptualization was reflected in their engagements with critical and feminist theory (Kessler, 1991) and with postmodern perspectives (Lather, 1991), which they used to critique the dominance of DAP.

\section{Key Themes of the Reconceptualist Movement}

Jipson (1991) outlined the reconceptualist movement's historical context during a wave of mass DAP standardization protocols in ECE programming and research. Early reconceptualists, inspired by such scholars as Jacques Derrida, Michel Foucault, and Jean-François Lyotard, addressed their concerns with DAP and laid a theoretical grounding for their critique that focused on equity, social justice, and resistance. As Jipson noted some 30 years ago in referring to the 1980s:

The past decade of "reconceptualizing [ECE]" has involved an intensive, scholarly rethinking of childhood education, with multicultural, critical, feminist, [post]colonial, and postmodern early childhood researchers calling to question dominant ideologies, knowledge, and educational practices. This recent work [in ECE] has opened up dialogue in the field by focusing on such issues as power relations within the adult/child dichotomy, the manifestation of social fears and obsession about curriculum content, and the control of women and children through the construction of educational standards. (pp. 3-4)

Foundational early childhood reconceptualist Gaile Sloan Cannella and colleagues (2007) highlighted the movement's postmodernist grounding, which sought to challenge the domination "of Enlightenment, modernist and Western interpretations of the world that assume the existence of universal truths or natural laws as applicable and generalizable to all human beings" (p. 693). In contrast to the objective and stable universal "truths" claimed by positivist research and structuralist paradigms within ECE, the reconceptualists adopted a social constructionist understanding of the human world that troubled privileged knowledge, such as scientific certainty, or what Michel Foucault named "regimes of the truth" (1975). By deconstructing developmental regimes of truth, and taken-for-granted certainties in their fields, reconceptualists reframed children in research as social constructions and suggested that their identities reflect the social, historical, and political condition in which they exist (Burman, 2016; Cannella, 1997). At the same time, it should be noted that in doing this reconceptualists are not dismissive of science, they are 
instead trying to acknowledge the complexity and multiplicity that is our reality and formulates our understanding and ways of making sense of the world beyond a universalized truth contrived from an Enlightenment/modernist perspective (Cannella, 1997; Dahlberg et al., 2007; Janzen, 2008).

The calls to reconceptualize ECE not only addressed the domination of developmental psychology in the Global North, but also its ethnocentric implications regarding certainty of knowledge and truth, which constitute what is an appropriate teaching practice for young people around the world. The reconceptualist movement began to deconstruct the Euro-American historical and cultural traditions that have been continually reflected and imposed in early childhood developmentalist frameworks. These interrogations of developmentalism revealed a privileging of the "Euro-American middle-class ... masculine ways of interpreting and being in the world" (Cannella et al., 2007, p. 694) that had reoriented already existing early childhood knowledge and practice towards Euro-American values and developmentalist logics (Cannella \& Viruru, 2004).

A developmental narrative that the reconceptualists began to trouble in their field was the "globalization of childhood" (Boyden, 1997) and the concept of the idealized child as understood through developmentalism, who is the benchmark against which all global children are compared. This universalization results in privileging U.S. and Global North models of child care and educational practices that often conflict with and devalue traditional and local cultural understandings of care and learning. Studies have noted this conflict and described the oppositional stances taken by affected communities to the globalization of the child, which has tended to disregard cultural values in the Global South and favor developmentalist frameworks that have been imposed onto children and families (Henward et al., 2018; Meyer, 2017).

The reconceptualists are foundational in revealing the domination of Global North conceptualizations of the child and the taken-for-granted assumptions within developmentalist practice models (e.g., Bloch, 1992; Swadener \& Kessler, 1991). In employing social justice and equity frameworks, they have sought to understand and challenge the impact of the sociopolitical context that has resulted in the universalization of a singular contemporary iteration of developmentalism. It is from their scholarship that those who followed and expanded on the reconceptualist movement began identifying their own work as "postdevelopmentalist": scholarship that sought to identify itself beyond the confines of linear developmental frameworks by using feminist poststructuralist and queer theoretical conceptualizations of gender and sexuality in ECE.

\section{Postdevelopmentalism and Feminist Poststructuralism}

Postdevelopmentalism emerged as a way of recognizing the postmodern shifts occurring within the field of ECE while "emphasizing ethical issues, cultural contexts, and the struggle for equity in the provision of learning experiences" (Edwards et al., 2009, p. 55). 
Postdevelopmentalsim also denotes a theoretical understanding of children's learning and development that is derived from the Vygotskian-inspired cultural-historical theory (Rogoff, 2003) along with critical, poststructural, and postmodern thinking (Edwards et al., 2009). These "alternative theoretical frameworks" for teaching and understanding children focus on the childin-context, often politically, rather than focusing on the child through developmental norms and on planning for individual developmental needs (Wood, 2009). Postdevelopmentalism distinctly prioritizes feminist and queer theorizing, as exemplified by Blaise's (2005a, 2005b, 2009, 2010) critiques.

Blaise (2005b) followed the reconceptualists' path by introducing new theoretical frameworks to inform research and teaching in ECE. As a postdevelopmentalist, Blaise's use of feminist poststructuralism and queer theory presents alternative frameworks that explore identities, diversity, and learning of children and youth while centering equity and social justice (Blaise, 2005b, p. 3). In Blaise's (2005b) book Playing it Straight, she used a feminist poststructural approach - one that engages both poststructuralism and feminism in understanding gender inequity (Weedon, 1997) and queer theory — in ECE research to help us focus on "how young children make sense of the politics of femininities and masculinities, and ... the complex ways they are doing gender in their everyday lives" (2005b, p. 4). Blaise and Affrica Taylor (2012) discussed their application of queer theory as a way to investigate "young children's gender construction" in order to become "aware of how the children behave in agreement with dominant gender discourses, negotiate the power relations of these discourses, and at the same time behave in accordance with the overarching discourse of heterosexuality" (p. 91). In relation to CYC, a postdevelopmentalist perspective in ECE, or a feminist poststructuralist one, could use queer theory in similar ways to go beyond developmentalist narratives in reconceptualizing the field.

Through feminist poststructuralist and queer theoretical frameworks, Blaise (2005b) not only analyzed gender construction in the classroom but also the reliance on both biological ("they're just born that way") and socialization-based ("they're just doing what they see") theories of gender development (pp. 11-14). As noted by Blaise, both of these approaches are considered "simple explanations", or "essentializing theories", of children's gender development, which have the failing that they ignore child autonomy and children's ability to "distinguish for themselves ways in which the social world is organized and how they take an active part in the construction of gender" (p. 14). In this way, Blaise challenged traditional Western understandings of biological and socialized sex development — sex and gender — and invited resistance to these "simple" understandings in favor of more political and social contextual understandings. Blaise (2005b) suggested that children negotiate gender, or "play it straight" (p. 27), through their interactions with adults and peers in an attempt to meet gender expectations. Her works suggest that sex and gender are political, dynamic, and socially constructed, in contrast to gender development and developmentalist notions that often isolate children from their social, cultural, and political context, which may be seen as an "extra", or not integral to "good" early years practice (Browne, 2004, p. 17). 
A lot has changed in ECE in relation to gender equity since the publication of Blaise's (2005a, 2005b, 2009) work on gender construction in the classroom. For example, guides and models for supporting gender diversity in ECE have been researched and considered by scholars and educators in the past decade; nevertheless, early childhood teacher education, and guidance for early educators and practitioners, is still limited in its understanding of gender in early childhood (Chapman, 2021) in that gender is often couched within a broad narrative of recognition as a way of addressing contemporary shifts in gender expression and gender-transgressive visibility in early childhood environments. For example, the NAEYC's (2020) most recent DAP position statement suggested that "the historical and current inequitable distribution of societal power and privilege on the basis of race, ethnicity, gender, language, disability, and other social identities results in limited opportunities and harms children" (p. 4) and needs to be "recognized" and "understood". A narrative that encourages recognizing and understanding inequalities is a step forward, but still incomplete when it comes to making a practical shift in DAP. What is still needed is a queering of developmentalist models that questions the political and gendered assumptions within these frameworks while engaging with contemporary gender and sexuality scholarship in order to develop critical conceptualizations that allow for queer(er) engagements in ECE and CYC and a more gender-inclusive future. Postdevelopmentalists have contributed to making such a change by seeking to go beyond developmentalism through making room for other perspectives, such as feminist and queer theoretical strategies that promote gender equity. In doing so, they have helped to change the landscape of ECE practice today.

Blaise's (2005a, 2005b, 2009, 2010, 2014) work on children, gender, and society is part of a larger conversation about future possibilities in queering developmentalism. The ways that postdevelopmentalist's have deployed queer theory in ECE by questioning developmental narratives leaves room for growth and queer(er) potentialities for contemporary applications in CYC. For example, Blaise (2014) noted that, "While postdevelopmental research has made significant contributions to challenging the assumptions of developmental approaches to gender, it still often leaves the privileged western lens in place" (p. 125). In queering developmentalism in $\mathrm{CYC}$, a postdevelopmentalist future requires a decentering of the Western lens that has often dominated the field.

While the reconceptualists and postdevelopmentalists focused on reconceiving ECE, their philosophies and perspectives are a part of a critical past that can inspire a queer(er) future for interrogating CYC's reliance on developmentalist frameworks. In acknowledging that the postdevelopmentalist scholarship shared here is in response to past conversations in ECE, it should also be noted that these scholars' use of queer theory has had a major impact in ECE and can potentially have an impact on CYC in taking the field forward towards critical engagements with queer theory and practice. 
International Journal of Child, Youth and Family Studies (2021) 12(3/4): 104-128

\section{Queer Studies, Transgender Studies, and Child and Youth Developmentalism}

Many queer scholars are not unfamiliar with children, youth, and development (Edelman, 2004; Gill-Peterson, 2018; Probyn, 1995; Sedgwick, 1991; Stockton, 2009), yet queer scholarship within CYC is limited. Queer studies - the examination of issues related to identity, sexuality, and LGBTQ+ people and cultures - has its home in the humanities but has expanded into other disciplines. Within queer studies, queer theory has developed as an analytical viewpoint that uses poststructuralist philosophy and analysis to question the socially constructed categories of sexual identity (such as gay, lesbian, straight, heterosexual, normal, abnormal; Branch, 2003; Burgett \& Hendler, 2020). Inspired by social movements that addressed the AIDS crisis in the late 20th century, specifically ACT UP 2 , queer theory sought to bring together deconstructive practices and grass roots organizing (Ghaziani \& Brim, 2019). Queer theory, often used intersectionally, quickly developed as a critical lens to question not only sexual identities, but all categories that are seen as "stable, transhistorical, or authentic", including racialized categories and the categories of child and adult, which are intrinsically connected with sexuality (Somberville, 2014, p. 206). Owen (2010) developed this intersection by stating that "queer theory understands the categories of gender and sexuality not as stable, but as shifting, malleable, contextual - and I see that theorized complexity as belonging to the child" (p. 255). While some queer theorists situate the child at the center of their work, their analyses are often distant from the practical implications of queer theory in the everyday lives of children and youth, and, as noted above, queer theory has challenged DAP within ECE (Blaise, 2014; Janmohamed, 2010, 2011; Robinson, 2005). As well, in critical youth studies, Owen (2020) has queered adolescence in pursuit of new possible conceptualizations of young people. Nevertheless, this scholarship remains limited in impact and often remains exclusively within the academy.

\section{Meeting at the Intersections of Queer and the Child}

Queer scholars disrupt the existing categories of gender and sexuality, often destabilizing various binary assumptions and social constructions within dominant discourses. In its destabilizing aim, queer theory deconstructs the gendered and sexual constructions of the child and childhood through queer readings of children's literature and media. For example, queer scholars have looked to Jacqueline Rose's (1992) feminist interrogations of children's literature and her understanding of how the figure of the child and childhood are operated and constituted through fantasy and fiction.

Rose (1992) argued that the conceptualization of the child and childhood emerges through adult desires. Most importantly, what Rose emphasized in her work is how certain taken-forgranted assumptions about childhood, such as innocence, are considered not a given "property of childhood but ... a portion of adult desire" (Rose, 1992, p. xii). Through adult desire, "children's fiction sets up a world in which the adult comes first (author, maker, giver) and the child comes

\footnotetext{
${ }^{2} \mathrm{See}$ https://actupny.com/contact/
} 
after (reader, product, receiver)" (Rose, 1992, pp. 1-2). This relationship between the adult and the child benefits the adult as they are granted the power to build the "image of the child inside the book ... in order to secure the child who is outside the book" (Rose, 1992, p. 2). Through this relationship, Rose's work suggests that the figure of the child "works to conceal cultural anxieties around sex and identity" (Rudd \& Pavlik, 2010).

In a queer scholarly engagement with Rose's work, Gabrielle Owen (2010) stated that, "queer theory is concerned with the ways of being and relating that are possible when the normative sequence of heterosexual romance, marriage, and reproduction renders those who do not follow the sequence invisible, irrelevant, or impossible" (p. 259). In analyzing those who "do not follow" normative sequences of development, Owen looks to the figure of the child and suggests that children are tasked with the important role of maintaining that sequence along with the separation from the adult, or all "that which is before heterosexuality" (Owen, 2010, p. 259). This separation situates childhood as a maintained stage in which the child is assumed to be asexual, naive, and innocent. In looking at socially constituted conceptualizations of child and adult development, queer theorists have become interested in examining the child who does not follow such normative developmental sequences and frameworks, which have often rendered queer children invisible. By constituting both normalized and atypical childhoods through stories and fantasies in children's literature, queer scholars often look to the figure of the child, instead of the child as such, in considering how children become. This framing of analysis allows queer scholars to consider the language and the contextual elements that are used to define the "normal child" against those who deviate from such conceptions. Through critically examining Rose's scholarship, and that of others who have analyzed the cultural understanding of the child within literature (e.g., Kincheloe, 1992), queer theorists consider who constructs the literary, scholarly, and social narratives that dictate the cultural understanding of the child and childhood and all who stray from such conceptual boundaries.

Queer theorist Kathryn Bond Stockton (2009) also described the child as socially constructed but drew from various media sources, not necessarily designed for or aimed at children, to analyze how children are constructed alongside and against queerness. In bringing the child and queer together, Stockton argued that all children are "strange", or queer, and that all children are framed as fundamentally in need of adult interventions steering them towards an appropriate linear pathway of growing up, "towards full stature, marriage, work, reproduction and the loss of childishness" (p. 4). According to Stockton, "growing up" can be seen as the normative orientation of developmentalist trajectories that situate all children as asexual, then youth as hyper(hetero)sexual, and finally adults as maturely (hetero)sexual. Stockton troubled linear narratives of growth by delving into children's "sideways growth" (p. 11); that is, their deviation from normative and developmentally appropriate behaviors and desires towards various versions of the "queer child". Stockton went on to consider adult control of such strangeness through "children's legally enforced delays" (p. 4), which place the queer child on a disciplinary path of regulations and restraints that intend to thwart inappropriate, alternative, sideways growth. 
Through Stockton's "queer child", childhood and youth are understood as states of straight becoming where youth are both "not-yet-straight" and "not allowed to be sexual" (p. 7) until "we say it's time" (p. 6). In essence, Stockton suggested that developmentalist frameworks view all children as queer, strange, and threatening, and as such children are regulated and moved through imaginary chambers of development constructed as childhood until they are recognizable as adult. The queer child, then, is one "who...can't 'grow up' [and instead] grows to the side of cultural ideals", resisting "stable" identity formation and developmental stages that construct childhood, youth, and adulthood (p. 13).

Similarly, Regales (2008), in writing about experiences of young trans zine writers, queered notions that a fixed or stable identity is a hallmark of successful navigation of the developmental tasks associated with adolescence and suggested that many young people's well-being rests precisely on embracing identity as fundamentally unstable, partial, and situated, or as the title of her paper suggests, "fluid as fuck". As Regales showed, for these writers, imposing the developmental trajectory of adolescence restricts young people and serves as a tool of normalization rather than a description of human growth and change. Donald and Krahn (2014) also queered developmental understandings of young people's growth as linear and ordained along a normalized trajectory. Taking Stockton's (2009) notion of "growing sideways" as a starting point, Donald and Krahn conceptualize growth and change in rhizomatic terms, in which individual growth occurs alongside, in complex relationships with, and often sideways to the growth of others. In this context, children may not grow up as much as they grow with their environments. This queered critique of developmentalism challenges the central precept of the notion of adolescence: that the developmental task of adolescence involves differentiation. It asks us to consider youth whose traditions and cultures foster cohesion and rhizomatic growth over individuation. Owen (2020) also emphasized the potentials for young people's relational futures offered by queering adolescence and adolescent theory "in order to imagine alternate ways of conceptualizing the stages of human life" (p. xv).

In their recent scholarship, Hannah Dyer (2017) directly addressed DAP as "destructive to some children's imaginative and social capacities when not attuned to their possible queer presents and futures" (p. 291). Dyer's use of "queer" in their work "is not only meant to register a child's potential desire for same-sex relations or LGBTQ identity but also gestures toward more expansive ways to account for children's deviances from normativity" (p. 293). As Dyer attempted to "undo the innocent Child" (p. 293), they situated the queer child as one who is excluded from the traditional formation of childhood innocence and simplicity, who becomes instead a surplus that "can't be explained or contained by developmental theory" (Dyer, 2020, p. 26). In situating the queer child in this way, Dyer showed that developmentalist frameworks are limiting and noted a concern raised by critical scholars in ECE that studies of children's education are "keen on securing knowledge concerning developmental stages and building professional capacities for realigning children's growths that occur along calculated, horizontal, and heteronormative lines" (p. 292). Dyer suggested that queer sexualities in ECE settings are erased and ignored by 
prioritizing such knowledge. While Dyer mentioned the large amount of literature that concerns LGBTQ teachers and parents as "its subjects of inquiry" (p. 292), they suggested pushing the use of queerness in ECE further as "a methodological approach to child development and education [that] can more generally disrupt teleologically constructed narratives of growth that require a developmental sequence which culminates in normalcy" (p. 292). According to Dyer, such an analysis, rooted in queer theorizing, has the potential to step back from calculating "the child's future before it has the opportunity to explore desire" (p. 292) and allows for a possible scholarly and applied future between "queer" and "childhood" that is beyond developmentalism.

In showing that queer and transgender children are often understood as those who deviate from and disrupt developmentalist frameworks because of their failure to fully achieve a fixed and stable self, queer scholars and activists politicize dominant conceptualizations of children, childhood, and youth. As they investigate the social and political conditions in which transgender children and gender transgressive children exist, they decenter and disrupt a White heterosexual politic that has historically dominated CYC and developmentalist orientations. In engaging in critical and interdisciplinary conceptualizations of the transgender child, these scholars offer us a reorientation of our understanding of what constitutes the child within developmentalist frameworks and take us closer to a queerer future in CYC.

\section{The Transgender Child, Transgender Studies, and Developmentalism}

In the first volume of TSQ: Transgender Studies Quarterly, transgender studies is described as a research approach that 'revolves around the category 'transgender' itself — its history, dissemination, application, uptake, logics, politics, and ongoing definitional and categorical transformations" (Stryker \& Currah, 2014, p. 5). While transgender studies have "taken shape ... in the shadow of queer theory" (p. 214) by sharing similar histories, methods, and methodologies, these studies have distinguished themselves as a separate field of study (Keegan, 2020a, 2020b; Stryker, 2004). Transgender studies are not an addendum to queer studies, but instead, are a way to consider a specific understanding of children and youth in relation to a developmentalist framework. They offer us an approach that analyzes the historical contexts and the current social and political contexts surrounding transgender and gender-transgressive children, an approach that helps us to acknowledge children who queer development and who queer childhood and to understand how their lives have been shaped by being marked as trans, queer, intersex, nonnormative, strange, and so on.

Transgender scholars often look to the history of transgender children and the role of psychiatric interventions in the lives of these children in the 20th and 21 st centuries. In assisting us with the relatively new contemporary understanding of the "transgender child" in EuroAmerican society (Gill-Peterson, 2018; Meadow, 2014), transgender scholars show us that transgender children are outside the developmentalist orientation as it is understood in the medical and psychiatric fields and thus have often been identified as "effeminate boys" and "masculine girls" (Sedgwick, 1991). As well, in her book, Histories of the Transgender Child (2018), 
transgender historian Jules Gill-Peterson showed us that transgender children are not a new phenomenon and that "multiple trans childhoods" (p. 95) have long existed and played a crucial role in the forced medicalization of sex and gender during the 20th century.

Developmentalist narratives have been critiqued as models in which transgender children are maneuvered into designated positions without agency or autonomy (Meadow, 2014). As Claudia Castañeda (2014) showed, the mode of control within developmental frameworks emphasizes the child's process towards becoming and the movement of the child from birth to adulthood is premised on their fixed gender at birth and their successful performance of that gender into maturity. Thus, to "become fully gendered" (p. 59), one must follow a normal developmental pathway into mature adulthood; before adulthood, the child is never seen as fully formed, nor its gender as fully "matured", and is therefore "seen as not fully capable of knowing its own gender" (p. 59). Seen through this framework and understanding, children are denied control of their own bodies and deemed to lack an understanding of gender. Even if children seek medical methods towards transitioning, Castañeda observed that the objective of treatment is to put the child "on hold until it reaches a more fully adult state of reason", or treat only "to a degree that the process may be reversed" and potentially "put back on course" (p. 60). It is because they see children as being in a state of becoming that modern medical professionals design treatments to guide gender performances that adhere to normative gender constructions. As conceptions of appropriate gender and identity development have become taken for granted, children who deviate from them become targets for social control.

The NAEYC's (2020) DAP statement does note that educators should be aware of their own and others" "implicit biases", "social inequalities", and potential "microaggressions" in the classroom while focusing on "diversity" and "equity" in relation to gender (p. 12). However, the statement does not expand on how DAP addresses trans and queer identities or queer families. While the NAEYC's DAP statement suggests that, based on "current knowledge and research in the field of ECE, child development, and related disciplines" (p. 86), it is important for educators to "recognize" and "respect" the "unique qualities" of non-normative gender expression or identity within a developmentalist framework, the child continues to be viewed as being in an individualized and apolitical state of gendered becoming. So, while the recent DAP position statement does expand on the acknowledgement of systems of power and privilege, the emphasis is still on doing this within a developmentalist framework. The political implications of DAP for children and youth have not as yet been examined; thus, DAP is still a potential site for queering and for the purposeful inclusion of transgender studies in ECE and CYC. By queering DAP, we can support moving beyond the apolitical borders of the still-dominant developmentalist framework in these fields and work towards creating an active historical and political understanding of the children and youth that we care for. 
International Journal of Child, Youth and Family Studies (2021) 12(3/4): 104-128

\section{Implications for Queering Developmentalism in CYC}

In a recent issue of the International Journal of Child, Youth and Family Studies, Wolfgang Vachon (2020) addressed queer futures in CYC by inviting "readers to consider a queer CYC imagination, one that recognizes, perhaps even celebrates, desire, sex, identity, theory, and politics" (p. 64). We understood Vachon's five "initial flirtations" (p. 74) as methods by which one can queer the often apolitical, neoliberal, heteronormative, and racialized developmentalist conceptualizations of children, youth, and care. As we move to understanding our place in the "growing tension between 'development' and 'social justice' approaches to CYC practice" (p. 76), we recognize that queer engagements within CYC are tasked with demanding critical inquiries within the field to address the social injustices that are connected to formulating children's and youth's experiences in terms of developmentalist notions of growth. We question developmentalism and its role in CYC, its contemporary iteration in CYC scholarship, and its practicality for current CYC practitioners (CYCPs). Following in the path of reconceptualists, postdevelopmentalist, and queer and transgender studies scholars, we suggest that queering has the ability to plant the seeds to grow the queer imagination within CYC that can be found in the nascent reluctance to rely on developmentalist frameworks in practice and research. The histories of resistance and critical scholarship introduced in this article show that in CYC it is now impossible to nullify the queer imagination and the political actions, desires, and critiques that have been growing for decades in various youth care and educational fields - critiques that signal a vast horizon before us in which a queer(er) future is possible. Thus, in following the continued disordering, deconstruction, and queering of developmentalist frameworks, we see glimpses of other practices and possibilities that are not yet present in $\mathrm{CYC}$ but that have been felt, and should be encouraged as a way to expand the field in a vital direction.

As noted above, developmentalist frameworks situate the child as becoming. We return to our introductory question: What would it mean to queer the reductionist understanding of a young person as one who is becoming, and an adult as one who has arrived? With regard to queering perceptions of the child, we turn to Castañeda (2014):

Transgender childhood becomes a threat to normative gender development and so to (normal) gender itself; if gender can shift away from the expected normal binary of male and female associated with particular bodily signs, then how can we know the gender of any child-body? (p. 60)

We take this to mean that we can queer developmentalist frameworks by questioning how we have come to know the child through developmentalist frameworks.

In asking "how can we know?", we suggest that we submit to "not knowing" and relinquish our perceived knowing of "normal" and of fully understanding gender. For if we cannot know the "child-body", it would be advantageous to queer and interrogate developmentalist impulses in CYC. Recognition of the transgender child, the queer child, and all children who do not fit neatly within the developmental frameworks signals a critical juncture within CYC at which the question 
shifts from one that asks, "Which developmental models should we use in understanding the child?", to one that instead asks, "How have we have come to conceptualize the child in relation to professionalism, care, politics, and society?" Looking to past resistance movements, counternarratives, and queering practices, we invite scholars to answer the call to move towards a queer political future in which we make strange our knowledge claims in order to align CYC with contemporary commitments to social justice and equity for children and youth.

We also note that these queering conversations are not isolated from, nor in contrast to, the critical and burgeoning anti-racist, post-humanist, and post-colonial scholarship in CYC today (Daniel, 2020; James, 2020; Murris \& Borcherds, 2019; Saraceno, 2012). Instead, a queering of developmentalism joins with such critical work in CYC: it too grows from a history of resistance in ECE and CYC that intersects with the political and cultural complexity of working with children and youth in relation to race, gender, sex, and coloniality. It must also be noted that many, but not all, of the authors of critical ECE histories and the queer scholars centered here are predominantly White or are from Euro-Western, Global North contexts. Queer of color scholars have critiqued queer studies and the domination of White queer theoretical engagements in their field and are pushing scholars and researchers to see how race and Western-centrism shapes the categories of sex and gender (Ferguson, 2003; Mayo, 2017). A queering of developmentalism in CYC through queer of color engagements in conjunction with Two-Spirit and Indigiqueer scholars has the potential to further the work of decentering White domination. The call to queer developmentalism draws on and extends the critical histories of ECE and CYC. With this queer reflex, we can contest existing categories, and thereby open new theoretical interrogations that contribute to the continual decentering of Euro-Western, Global North perspectives in CYC scholarship.

As Vachon (2020) stated, "caring is not neutral" and "caring is a political act" (p. 73). The intersections of systems of care and political systems are not unfamiliar in CYC: Berry and colleagues (2018) acknowledged that "caring in the field of child and youth care requires a radical shift in how we as CYCPs situate ourselves within an increasingly precarious global landscape" (p. 49). In conjunction with current critical scholarship, intersectional queer political engagements can be an important part of a needed radical shift in CYC, especially in questioning dominant narratives in the field and listening for and to the voices that are left on the margins. We also foresee queer of color engagements within $\mathrm{CYC}$, as the queering of developmentalism is not isolated from understanding racialized practices, politics, and research in CYC. While developmentalist frameworks continue to be situated in CYC practice as neutral and apolitical tools, a queer political imaginary within CYC broadens our field and can point the way towards a queer future in which developmentalism is interrogated for its political implications in our current global landscape. Queering CYC allows for a possible future in the field that is beyond developmentalism. 
International Journal of Child, Youth and Family Studies (2021) 12(3/4): 104-128

\section{References}

Berry, A., Do Nascimento, A., \& Pacini-Ketchabaw, V. (2018). Pedagogies of care: Thinkingwith and paying attention. Relational Child \& Youth Care Practice, 31(2), 49-57.

Blaise, M. (2005a). A feminist poststructuralist study of children "doing" gender in an urban kindergarten classroom. Early Childhood Research Quarterly, 20(1), 85-108. doi:10.1016/j.ecresq.2005.01.002

Blaise, M. (2005b). Playing it straight: Uncovering gender discourse in the early childhood classroom (1st ed.). Routledge.

Blaise, M. (2009). "What a girl wants, what a girl needs": Responding to sex, gender, and sexuality in the early childhood classroom. Journal of Research in Childhood Education, 23(4), 450-460. doi:10.1080/02568540909594673

Blaise, M. (2010). Kiss and tell: Gendered narratives and childhood sexuality. Australasian Journal of Early Childhood, 35(1), 1-9. doi:10.1177/183693911003500102

Blaise, M. (2014). Gender discourses and play. In L. Brooker, M. Blaise, \& S. Edwards (Eds.), The Sage handbook of play and learning in early childhood (pp. 115-127). Sage Publications Ltd.

Blaise, M., \& Affrica, T. (2012). Using queer theory to rethink gender equity in early childhood education. Young Children, 67(1), 88-96.

Bloch, M. N. (1992). Critical perspectives on the historical relationship between child development and early childhood education research. In S.A. Kessler \& B. B. Swadner (Eds.), Reconceptualizing the early childhood curriculum: Beginning the dialogue (pp. 3-20). Teachers College Press.

Bloch, M. N. (2013). Reconceptualizing theory/policy/curriculum/pedagogy in early child (care and) education: Reconceptualizing early childhood education (RECE) 1991-2012. International Journal of Equity and Innovation in Early Childhood, 11(1), 21.

Bohart, H., \& Procopio, R. (2017). Spotlight on young children: Social and emotional development. National Association for the Education of Young Children.

Boyden, J. (1997). Childhood and the policy makers: A comparative perspective on the globalization of childhood. In A. Prout \& A. James (Eds.), Constructing and reconstructing childhood: Contemporary issues in the sociological study of childhood (pp. 187-225). Falmer Press.

Branch, M. A. (2003). Back in the fold. Yale Alumni Magazine, 66(6). http://archives.yalealumnimagazine.com/issues/03 04/kramer.html 
International Journal of Child, Youth and Family Studies (2021) 12(3/4): 104-128

Bredekamp, S. (Ed.). (1987). Developmentally appropriate practice in early childhood programs serving children from birth through age 8. National Association for the Education of Young Children.

Bredekamp, S., \& Copple, C. (Eds.). (1997). Developmentally appropriate practice in early childhood programs serving children from birth through age 8 (Rev. ed.). National Association for the Education of Young Children.

Browne, N. (2004). Gender equity in the early years. Open University Press.

Burman, E. (2016). Deconstructing developmental psychology (3rd ed.). Routledge.

Cannella, G. S. (1997). Deconstructing early childhood education: Social justice \& revolution. Peter Lang.

Cannella, G. S., Swadener, B., \& Che, Y. (2007). Reconceptualists. In R. S. New (Ed.), The early childhood education: An international encyclopedia (pp. 693-696). ABC-CLIO.

Cannella, G. S., \& Viruru, R. (2004). Childhood and postcolonization: Power, education, and contemporary practice. Routledge.

Castañeda, C. (2014). Childhood. TSQ: Transgender Studies Quarterly, 1(1-2), 61. doi:10.1215/23289252-2399605

Chapman, R. (2021). Moving beyond 'gender-neutral': Creating gender expansive environments in early childhood education [Online]. Gender and Education, 1-16. $\underline{\text { doi:10.1080/09540253.2021.1902485 }}$

Copple, C., \& Bredekamp, S. (Eds.). (2009). Developmentally appropriate practice in early childhood programs serving children from birth through age 8 (3rd ed.). National Association for the Education of Young Children.

Council on Social Work Education. (2015). Educational policy and accreditation standards for baccalaureate and master's social work programs. https://www.cswe.org/getattachment/Accreditation/Accreditation-Process/2015EPAS/2015EPAS Web FINAL.pdf.aspx

Dahlberg, G., Moss, P., \& Pence, A. (2007). Beyond quality in early childhood education and care (2nd ed.). Routledge.

Daniel, B.-J. M. (2020). Embedding anti-oppression and anti-racism perspectives in the field of child and youth care: A case for rearticulating relational care [Online]. Child \& Youth Services, 1-27. doi:10.1080/0145935x.2020.1840348 
International Journal of Child, Youth and Family Studies (2021) 12(3/4): 104-128

DeVries, R. \& Sales, C. (2010). Ramps and pathways: A constructivist approach to physics with young children. National Association for the Education of Young Children.

Donald, D., \& Krahn, C. (2014). Abandoning pathologization: Conceptualizing Indigenous youth identity as flowing from communitarian understandings. In A. Ibrahim \& Steinberg, S. R. (Eds.), Critical youth studies reader (pp. 114-129). Peter Lang. doi:10.3726/978-1-4539$\underline{1271-3}$

Dyer, H. (2017). Queer futurity and childhood innocence: Beyond the injury of development. Global Studies of Childhood, 7(3), 290-302. doi:10.1177/2043610616671056

Edelman, L. (2004). No future: Queer theory and the death drive. Duke University Press.

Edwards, S., Blaise, M., \& Hammer, M. (2009). Beyond developmentalism? Early childhood teachers' understandings of multiage grouping in early childhood education and care. Australasian Journal of Early Childhood, 34(4), 55-63. doi:10.1177/183693910903400408

Elkind, D. (2015). Giants in the nursery: A biographical history of developmentally appropriate practice. Redleaf Press.

Epstein, R. (2007). The case against adolescence: Rediscovering the adult in every teen. Quill Driver Books/Word Dancer Press.

Erikson, E. (1950). Childhood and society. Norton.

Erikson, E. (1968). Identity: Youth and crisis. Norton.

Ferguson, R. A. (2003). Aberrations in Black: Toward a queer of color critique (1st ed.). University Of Minnesota Press.

Finn, J. (2009). Making trouble: Representations of social work, youth, and pathology. In L. M. Nybell, J. J. Shook, \& J. L. Finn (Eds.), Childhood, youth, and social work in transformation: Implications for policy and practice (pp. 37-66). Columbia University Press.

Flavell, J. H. (1992). Cognitive development: Past, present, and future. Developmental Psychology, 28(6), 998-1005. doi:10.1037/0012-1649.28.6.998

Foucault, M. (1975). Discipline and punish: The birth of the prison (A. Sheridan, Trans.). Gallimard.

Ghaziani, A., \& Brim, M. (2019). Four provocations for an emerging field. In A. Ghaziani \& M. Brim (Eds.), Imagining queer methods (pp. 3-27). New York University Press.

Gill-Peterson, J. (2018). Histories of the transgender child (3rd ed.). University Of Minnesota Press. 
International Journal of Child, Youth and Family Studies (2021) 12(3/4): 104-128

Henward, A. S., Tauaa, M., \& Turituri, R. (2018). Contextualizing child-centeredness: Lessons from an American Samoan Head Start. Policy Futures in Education, 17(3), 383-401. doi:10.1177/1478210318813249

James, J. (2020). Fiction, empathy, and gender diversity: Exploring the impact of using a novel in a child and youth care classroom. International Journal of Child, Youth and Family Studies, 11(3), 126-145. doi:10.18357/ijcyfs113202019707

Janmohamed, Z. (2010). Queering early childhood studies: Challenging the discourse of developmentally appropriate practice. The Alberta Journal of Educational Research, 56(3), 304-318.

Janmohamed, Z. (2011, June 9). When queer enters early childhood teacher training [Paper presentation]. Global Realities \& Possibilities in Queer Contexts: A 2011 CASAE-AERC PreConference, University of Toronto, Ontario, Canada.

Janzen, M. D. (2008). Where is the (postmodern) child in early childhood education research? Early Years, 28(3), 287-298. doi:10.1080/09575140802393827

Jipson, J. A. (2001). Introduction: Resistance and representation: Rethinking childhood education. In J. A. Jipson \& R. I. Johnson (Eds.), Resistance \& representation: Rethinking childhood education (pp. 1-12). Peter Lang.

Keegan, C. M. (2020a). Against queer theory. TSQ: Transgender Studies Quarterly, 7(3), 349353. doi:10.1215/23289252-8552978

Keegan, C. M. (2020b). Getting disciplined: What's trans* about queer studies now? J Homosex, 67(3), 384-397. doi:10.1080/00918369.2018.1530885

Kessler, S. A. (1991). Alternative perspectives on early childhood education. Early Childhood Research Quarterly, 6(2), 183-197. doi:10.1016/0885-2006(91)90006-7

Kincheloe, J. L. (1992). Child loving: The erotic child and Victorian culture. Routledge.

Koralek, D., Bohart, H., \& Charner, K. (2015). Spotlight on young children: Exploring play. National Association for the Education of Young Children.

Lanser, S. S.. (2018). Queering narrative voice. Textual Practice, 32(6), 923-937. doi:10.1080/0950236X.2018.1486540

Lather, P. (1991). Getting smart: Feminist research and pedagogy with/in the postmodern. Psychology Press.

Lesko, N. (1996). Denaturalizing adolescence: The politics of contemporary representations. Youth \& Society, 28, 139-161. doi:10.1177/0044118X96028002001 
International Journal of Child, Youth and Family Studies (2021) 12(3/4): 104-128

Lesko, N. (2001). Act your age! A cultural construction of adolescence. Routledge.

Lyotard, J.-F. (1984). The postmodern condition: A report on knowledge (G. Bennington \& B. Massumi, Trans.). University of Minnesota.

Males, M. (2009). Does the adolescent brain make risk taking inevitable? A skeptical appraisal. Journal of Adolescent Research, 24(1), 3-20. doi:10.1177/0743558408326913

Mattingly, M. A. (Ed.). (2010). Competencies for professional child \& youth work practitioners (Rev. 2010).

https://www.acycp.org/images/pdfs/2010_Competencies_for_Professional_CYW_Practitioner $\underline{\text { s.pdf }}$

Mayo, C. (2017). Queer and trans youth, relational subjectivity, and uncertain possibilities: Challenging research in complicated contexts. Educational Researcher, 46(9), 530-538. doi:10.3102/0013189x17738737

Meadow, T. (2014). Child. TSQ: Transgender Studies Quarterly, 1(1-2), 57-59. $\underline{\text { doi: } 10.1215 / 23289252-2399596}$

Meadow, T. (2018). Trans kids: Being gendered in the twenty-first century. University of California Press

Meyer, L. (2017). Resisting Westernization and school reforms: Two sides to the struggle to "communalize" developmentally appropriate initial education in Indigenous Oaxaca, Mexico. Global Education Review, 4(3), 88-107.

Miller, P. H. (2016). Theories of developmental psychology (6th ed.). Worth Publishers.

Mooney, C. G. (2005). Theories of childhood: An introduction to Dewey, Montessori, Erikson, Piaget \& Vygotsky (1st ed.). Pearson.

Muñoz, J. E. (2009). Cruising utopia: The then and there of queer futurity. New York University Press.

Murris, K., \& Borcherds, C. (2019). Childing: A different sense of time. In D. B. Hodgins (Ed.), Feminist research for 21st-century childhoods: Common worlds methods (pp. 197-208). Bloomsbury Academic.

National Association for the Education of Young Children. (2009). Developmentally appropriate practice in early childhood programs serving children from birth through age 8. https://www.naeyc.org/sites/default/files/globally-shared/downloads/PDFs/resources/positionstatements/PSDAP.pdf 
International Journal of Child, Youth and Family Studies (2021) 12(3/4): 104-128

National Association for the Education of Young Children. (2020). Developmentally appropriate practice. https://www.naeyc.org/sites/default/files/globallyshared/downloads/PDFs/resources/position-statements/dap-statement_0.pdf

O'Loughlin, M., \& Van Zile, P. T., IV. (2014). Becoming revolutionaries: Toward nonteleological and non-normative notions of youth growth. In A. Ibrahim \& S. R. Steinberg (Eds.), Critical youth studies reader (pp. 47-57). Peter Lang.

Owen, G. (2010). Queer theory wrestles the "real" child: Impossibility, identity, and language in Jacqueline Rose's “The Case of Peter Pan”. Children's Literature Association Quarterly, 35(3), 255-273. doi:10.1353/chq.2010.0007

Owen, G. (2020). A queer history of adolescence: Developmental pasts / relational futures. University of Georgia Press.

Pacini-Ketchabaw, V. (2012) Rethinking developmental theories in child and youth care. In A. Pence \& J. White (Eds.), Child and youth care: Critical perspectives on pedagogy, practice, and policy (Part 1, article 2). University of British Columbia Press.

Pacini-Ketchabaw, V., \& Pence, A. (2005). Contextualizing the reconceptualist movement in Canadian early childhood education. In Canadian Child Care Federation, Research Connections Canada (pp. 5-20). https://web.uvic.ca/fnpp/documents/01.Pacini_Pence_Contextualizing_000.pdf

Pence, A., \& White, J. (2012). Introduction. In A. Pence \& J. White (Eds.), Child and youth care: Critical Perspectives on pedagogy, practice, and policy. University of British Columbia Press.

Piaget, J. (1952). The origins of intelligence in children (M. Cook, Trans.). W W Norton \& Co. doi:10.1037/11494-000

Probyn, E. (1995). Suspended beginnings: Of childhood and nostalgia. GLQ: A Journal of Lesbian and Gay Studies, 2(4), 439-465. doi:10.1215/10642684-2-4-439

Prout, A. (2005). The future of childhood: Towards the interdisciplinary study of children. Routledge. doi:10.4324/9780203323113

Reconceptualizing Early Childhood Education. About RECE. (n.d.). https://receinternational.org/about/

Regales, J. (2008). My identity is fluid as fuck: Transgender zine writers constructing themselves. In S. Driver (Ed.), Queer youth cultures (pp. 87-103). University of New York Press. 
International Journal of Child, Youth and Family Studies (2021) 12(3/4): 104-128

Robinson, K. H. (2005). 'Queerying' gender: Heteronormativity in early childhood education. Australian Journal of Early Childhood, 30(2), 19-28. doi:10.1177/183693910503000206

Rogoff, B. (2003). The cultural nature of human development. Oxford University Press.

Roper v. Simmons, 543 U.S. 551 (2005). https://supreme.justia.com/cases/federal/us/543/03633/index.pdf

Rose, J. (1992). The case of Peter Pan, or the impossibility of children's fiction. University of Pennsylvania Press.

Rudd, D., \& Pavlik, A. (2010). The (im)possibility of children's fiction: Rose twenty-five years on. Children's Literature Association Quarterly, 35(3), 223-229. doi:10.1353/chq.2010.0001

Sanders, K., \& Farago, F. (2018). Developmentally appropriate practice in the twenty-first century. In M. Fleer \& B. van Oers (Eds.), International handbook of early childhood education (pp. 1379-1400). Springer.

Saraceno, J. (2012). Mapping whiteness and coloniality in the human service field: Possibilities for a praxis of social justice in child and youth care. International Journal of Child, Youth and Family Studies, 3(2-3), 248-271. doi:10.18357/ijcyfs32-3201210869

Schachter, E. P. (2005). Erikson meets the postmodern: Can classic identity theory rise to the challenge? Identity, 5(2), 137-160. doi:10.1207/s1532706xid0502_4

Schaefer, R. (2016). Teacher inquiry on the influence of materials on children's learning (Voices). Young Children, 71(5), 64-73. https://www.naeyc.org/resources/pubs/yc/nov2016/teacher-inquiry-materials

Sedgwick, E. K. (1991). How to bring your kids up gay. Social Text, 29, 18-27. doi: $10.2307 / 466296$

Sercombe, H. (2010). The gift and the trap: Working the "teen brain" into our concept of youth. Journal of Adolescent Research, 25, 31-47. doi:10.1177/0743558409353065

Singer, D. G., \& Revenson, T. A. (1996). A Piaget primer: How a child thinks (Revised ed.). Plume.

Somberville, S. B. (2014). Queer. In B. Burgett \& G. Hendler (Eds.), Keywords for American cultural studies (2nd ed., pp. 203-206). New York University Press.

Stockton, K. B. (2009). The queer child, or growing sideways in the twentieth century. Duke University Press. doi:10.1215/9780822390268

Stryker, S. (2004). Transgender studies: Queer theory's evil twin. GLQ: A Journal of Lesbian and Gay Studies, 10(2), 212-215. 
International Journal of Child, Youth and Family Studies (2021) 12(3/4): 104-128

Stryker, S., \& Currah, P. (2014). Introduction. TSQ: Transgender Studies Quarterly, 1(1-2), 118. doi:10.1215/23289252-2398540

Swadener, B. B., \& Kessler, S. (1991). Introduction to the special issue: Reconceptualizing early childhood education. Early Education and Development, 2(2), 85-94.

https://eric.ed.gov/?id=ej441900

Terrell v. State of Ohio, 18-5239 (2018). https://www.supremecourt.gov/DocketPDF/18/185239/52797/20180710155315344 Deshawn Terrell Final Cert Petition.pdf

Tisdall, E. K. M., \& Punch, S. (2012). Not so 'new'? Looking critically at childhood studies. Children's Geographies, 10(3), 249-264. doi:10.1080/14733285.2012.693376

Vachon, W. (2020). Queering child and youth care. International Journal of Child, Youth and Family Studies, 11(2), 61-81. doi:10.18357/ijcyfs112202019519

Walkerdine, V. (1993). Beyond developmentalism? Theory \& Psychology, 3(4), 451-469. $\underline{\text { doi:10.1177/0959354393034004 }}$

Weedon, C. (1997). Feminist practice and poststructuralist theory. Blackwell.

Wood, E. (2009). Introduction. In S. Edwards \& J. Nuttal (Eds.), Professional learning in early childhood settings (pp. 1-8). Brill | Sense. doi:10.1163/9789087907501_002

Wyn, J., \& White, J. (1997). Rethinking youth. Sage Publications Ltd. $\underline{\text { doi: } 10.4135 / 9781446250297}$ 